Potravinarstvo Slovak Journal of Food Sciences

vol. 15, 2021, p. 445-452

https://doi.org/10.5219/1623

Received: 22 March 2021. Accepted: 3 May 2021.

Available online: 28 May 2021 at www.potravinarstvo.com

(C) 2021 Potravinarstvo Slovak Journal of Food Sciences, License: CC BY 4.0

ISSN 1337-0960 (online)

\title{
BASIL - A COMPARISON OF THE TOTAL PHENOLIC CONTENT AND ANTIOXIDANT ACTIVITY IN SELECTED CULTIVARS
}

\author{
Martin Adámek, Jiří Mlček, Anna Adámková, Vít Guiglielmo Mišurec, Jana Orsavová, \\ Martina Bučková, Martin Búran, Anna Plášková, Lenka Kouřimská
}

\begin{abstract}
During the lifetime, the human body forms a considerable amount of free radicals damaging DNA, cell membranes, and their components. A wider application of basil (Ocimum basilicum), an aromatic plant and one of the common gastronomic commodities in the human diet could help to prevent the formation of free radicals and to remove them from the human body. Therefore, determination of antioxidant activity and total content of phenolic substances in selected cultivars of basil (Ohře, Sweet green, Salad leaf, Purple opal, Thai) in a fresh and frozen state and the mixture with another plant (garlic, mint, rocket, spinach) in the fresh and refrigerated state was performed. The total content of phenolic substances in basil was established by the spectrophotometric Folin-Ciocalteu method. DPPH spectrophotometric method was used to analyze the antioxidant activity. The results have shown statistically significant differences between basil cultivars under the same growing conditions. The values of antioxidant activity in frozen samples ranged from $5.1 \pm 0.4 \mathrm{mg} . \mathrm{g}^{-1} \mathrm{AA} F W$ to $11.71 \pm 0.18 \mathrm{mg} \cdot \mathrm{g}^{-1}$ AA FW and the total phenolic content varied between $2.77 \pm 0.16 \mathrm{mg} \cdot \mathrm{g}^{-1} \mathrm{GAE}$ FW in TH and $8.93 \pm 0.13 \mathrm{mg} \cdot \mathrm{g}^{-1} \mathrm{GAE}$ FW. A statistically significant difference between fresh and frozen samples was established only in the "Ohřre" cultivar. After the storage in cold temperatures, all mixtures showed a reduction in the antioxidant activity and total content of phenolic substances. The mixture of basil and mint performed the highest values of antioxidant activity and total content of phenolic substances and significantly differed from the other mixtures most often. The addition of basil and its mixtures to food and beverages can substantially increase their biological value and subsequently also the quality of human nutrition.
\end{abstract}

Keywords: Basil; Ocimum basilicum; total phenolic content; antioxidant activity; cultivar

\section{INTRODUCTION}

Basil is one of the basic commodities of world gastronomy, particularly Italian. It also plays an important role in Thai, Indonesian, French and Brazilian cuisine. The spread of basil all over the world has driven the development of an immense number of cultivars differing in shape, color, and size of leaves, plant height, taste, and aroma. The place of origin affects the resistance of the plant to higher or lower temperatures or temperature changes. Furthermore, the plants may differ, for example, also in their resistance to infestation. These properties influence the content of chemical substances including phenolic substances or other non-phenolic antioxidants with positive effects on human health.

Basil leaves rich in essential oils are mainly used to add flavor to food and drinks. These essential oils extracted from leaves show many positive impacts on human health. They can lower blood cholesterol, help to lower blood sugar in diabetic patients, and protect the stomach from ulcers (Dzida, 2010; Ezeani et al., 2017). Recently, in connection to the great success of sage seeds (known by its Mayan name chia), basil seeds have also emerged on the market. They are a good source of polyunsaturated fatty acids. Regular consumption of basil, both leaves, and seeds, provides many health benefits.

Basil (Ocimum basilicum, OB), also known as great basil, is one of the most common and available species of basil. It is usually an annual plant with a height of up to $60 \mathrm{~cm}$. Apart from a few subspecies that are purple, it is a brightly green plant (Hiltunen and Holm, 1999). Basil has a large number of cultivars and subspecies.

Basil leaves contain over $92 \%$ of free or bound water, approximately $5 \%$ of tannins and sitosterols, up to $1 \%$ of fats, $0.5-1.5 \%$ of essential oils, $0.17 \%$ of oleanolic acid; ursolic acid is present as well.

The composition of seeds is also remarkable, they contain $25 \%$ of fat, more than half of which consists of $\alpha$-linolenic acid, furthermore, minerals, vitamins, antioxidants, and phenolic substances (Hiltunen and Holm, 1999; Nirali et al., 2017).

Antioxidants are a very important group of substances with promising properties that prevent oxidation not only in 
food but also in the human body. The main groups of antioxidants in basil occurring primarily in its essential oils are phenolic antioxidants and endiols (Velíšek and Hajšlová, 2009). Endiol antioxidants are principally represented by ascorbic acid and its salts and derivatives. As part of its antioxidant activity, ascorbic acid reacts with reactive oxygen species, which slows down the oxidation of lipids, or with fatty acid radicals and alkoxy radicals. The efficiency of reactions with lipid radicals can be increased by the presence of tocopherols, which, in contrast to ascorbic acid, are fat-soluble (Velíšsek and Hajšlová, 2009).

Phenolic compounds can be generally defined as substances containing at least one benzene ring bonding at least one hydroxyl group or their functional derivatives. This group is extensive and diverse with several characteristics in common. Phenolic substances are often secondary metabolites of plants with antioxidant properties which are desirable and valued for a healthy human diet. Hydroxyl group of phenolic substances binds to hydroxy peroxide, superoxide, or hydroxyl radicals and thus prevents radicals from degenerative changes in the body (Velíšek and Hajšlová, 2009; Skinner and Hunter, 2013).

The proportion of individual substances in plant material obtained from basil (Ocimum basilicum) is influenced not only by growing conditions and cultivar but also by other factors, such as the method of treatment and storage time. This work aimed to determine the antioxidant activity and total content of phenolic substances in selected cultivars in fresh and frozen leaves of basil (Ocimum basilicum).

\section{Scientific hypothesis}

Hypothesis 1 - Individual basil cultivars differ in the total content of phenolic substances and antioxidant activity.

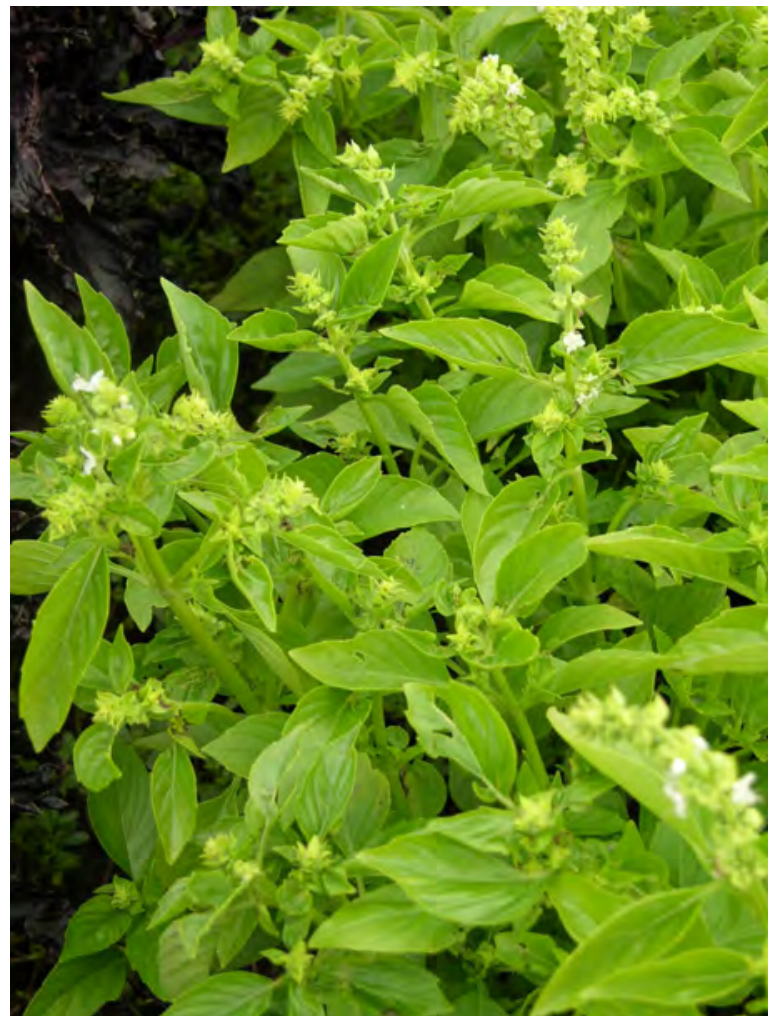

Figure 1 Ocimum basilicum - cultivar Ohře.
Hypothesis 2 - the value of the total content of phenolic substances and antioxidant activity differs in the case of direct processing and within the processing after the storage in a freezer at the temperature of $-18{ }^{\circ} \mathrm{C}$.

Hypothesis 3 - the total content of phenolic substances and antioxidant activity differ between the mixtures prepared from basil (Ocimum basilicum) and other plant material (garlic, mint, rocket, spinach).

\section{MATERIAL AND METHODOLOGY Samples}

The following basil cultivars were used for the research (Ocimum basilicum):

*Ohře (marked as $\mathrm{OH}$ ) - Czechoslovak cultivar (Figure 1), bright green, pleasant, and typically aromatic, with larger leaves and white flowers (Muráriková and Neugebauerová, 2018; GRIN Czech, 2021).

* Sweet green (marked as SG) - cultivar similar to the cultivar Ohře, medium-sized, shiny, and convex leaves, tastes sweeter, typical.

*Salad leaf (marked as SL) - very broad leaves with a typical green color and taste. However, compared to the Ohře and Sweet Green cultivars, the intensity of the taste is lower.

*Purple opal (marked as PO) - purple color (high content of anthocyanins in leaves (Simon et al., 1999)), it is used more for aesthetic purposes than taste (Figure 2).

* Thai (marked as TH)the - different shape of leaves, the coloring of stems red, taste and smell similar to anise or licorice, with better resistance to higher temperatures, but worse resistance to cold (Asijské bylinky, 2020; Semena.cz, 2020).

For selected cultivars, a difference in the analyzed values depending on the type of cultivar was expected.

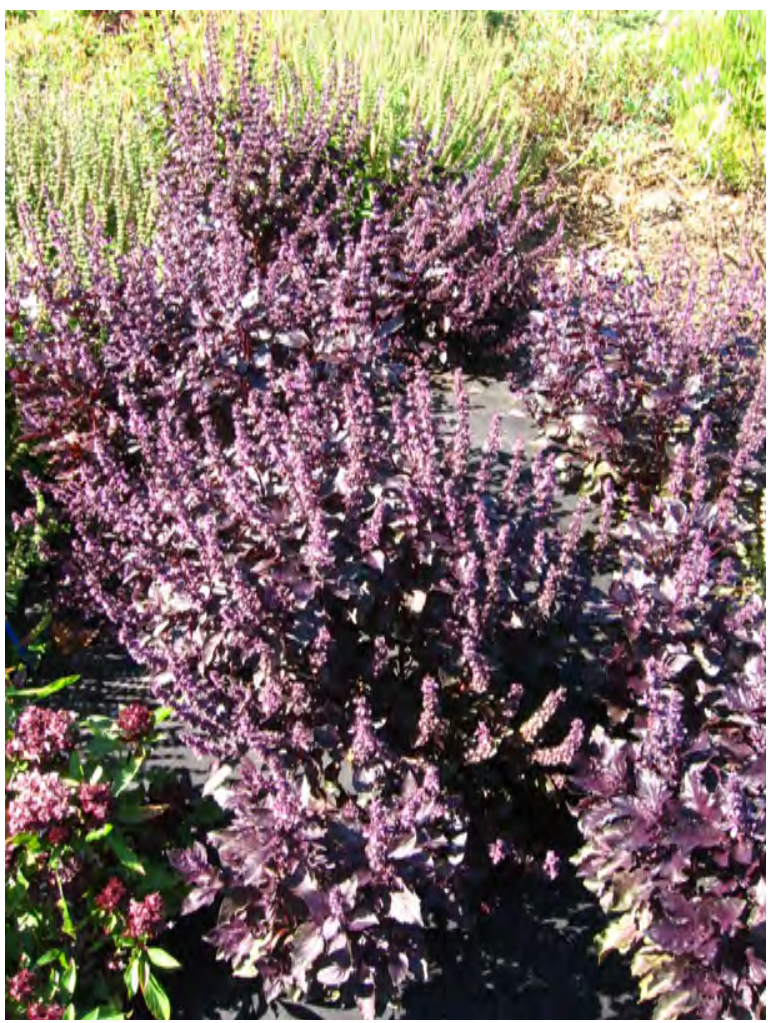

Figure 2 Ocimum basilicum - cultivar Purple opal. 
These samples originated from the same locality, were grown under the same conditions (the same soil composition, amount of sunshine,...) and agrotechnical treatments. For this reason, the dependence of these samples on different growing conditions for different sample origins was not expected.

The samples of basil of unknown variety marked as "XX1" and "XX2", were used for the research as well.

Furthermore, the mixtures of basil, cultivar "Ohře", with other plant material were produced with the following composition:

- mix 1 - basil, cultivar "Ohře" (92 wt. \%) + garlic (Allium sativum) (8 wt. \%) (marked as $\mathrm{OHG})$

- mix 2 - basil, cultivar "Ohře" (95 wt. \%) + peppermint (Mentha peperita) (5 wt. \%) (marked as OHM)

- mix 3 - basil, cultivar "Ohře" (95 wt. \%) + rocket (Eruca vesicaria) (5 wt. \%) (marked as OHR)

- mix 4 - basil, cultivar "Ohře" (90 wt. \%) + spinach

(Spinacia oleracea) (10 wt. \%) (labelled as OHS)

Chemicals

To prepare samples, an extraction solution in the composition of demineralized water and methanol was used (Methyl alcohol p.a., $\mathrm{CH}_{3} \mathrm{OH}, \mathrm{CAS}$ : 67-56-1, Penta, Chrudim, Czech Republic) in a ratio of 30:70.

The following chemicals were used to determine the total phenolic content:

Folin-Ciocalteu's reagent, (Sigma-Aldrich, St Louis, MO, USA)

Sodium carbonate anhydrous p.a. $\left(\mathrm{Na}_{2} \mathrm{CO}_{3}\right.$, Sigma Aldrich, St Louis, MO, USA)

Gallic acid (GAE) (Sigma Aldrich, St Louis, MO, USA)

Determination of antioxidant activity was performed using the following chemicals:

DPPH (2,2-diphenyl-1-picrylhydrazyl) (Sigma Aldrich, St Louis, MO, USA)

methanol (Methylalkohol p.a., $\mathrm{CH}_{3} \mathrm{OH}, \mathrm{CAS}$ : 67-56-1, Penta, Chrudim, CR).

All chemicals were of analytical reagent grade or equivalent analytical purity.

Demineralized water - 18.2 MOhm.cm, Milli-Q, Millipore was used throughout the experiment.
Animals and Biological Material:

Samples of cultivars Ohře, Purple opal, Sweet green, Salad leaf, and Thai were supplied by the Faculty of Horticulture of Mendel University in Brno, Czech Republic.

The samples were grown in the gene pool areas of this university in Lednice, Czech Republic (approximate GPS 48.79353068254463, 16.798598359226208). The location is in a temperate climate zone. The climate is continental with an average annual temperature of above $9{ }^{\circ} \mathrm{C}$ and average annual rainfall of around $520 \mathrm{~mm}$ (ČSÚ, 2016).

All other plant materials (samples of basil of unknown variety, garlic, peppermint, rocket, spinach) were purchased in a regular retail chain in Zlín, Czech Republic.

\section{Instruments}

The following instruments were used for the measurements:

Spectrophotometer Libra S6, Biochrom, Cambridge, UK (Determination of AA),

Spectrophotometer Specord 50 Plus, Analytik Jena, Jena, Germany (Determination of TPC),

Analytical scale Voyager PRO VP214C (Ohaus corporation, Pine Brook USA)

\section{Laboratory Methods}

Determination of the total phenolic content

Folin-Ciocalteu spectrophotometric method was selected to determine the total phenolic content (Cicco et al., 2009). The principle of this method is based on the reaction of the Folin-Ciocalteu reagent with phenolic substances (it reduces itself to a blue-colored mixture). The concentration of the reduced reagent is proportional to the amount of absorbed blue light at the wavelength $\lambda=765 \mathrm{~nm}$ (Costa et al., 2019; Albergamo et al., 2020).

\section{Determination of the antioxidant activity}

DPPH spectrophotometric method modified according to Brand-Williams was used to establish the antioxidant activity (Brand-Williams, Cuvelier and Berset, 1995). The principle of this method is based on the reaction of the stable free radical 1,1-diphenyl-2-picrylhydrazyl (DPPH). In the reaction of DPPH with an antioxidant, a radical is eliminated, and colorless products are formed from purple DPPH. The concentration of antioxidants and their activity is proportional to the decrease of absorbance.

Table 1 Antioxidant activity (AA) and total phenolic content (TPC) in cultivars of brasil (Ocimum basilicum) in fresh and frozen state.

\begin{tabular}{|c|c|c|c|c|}
\hline \multirow[t]{2}{*}{ Cultivars } & \multicolumn{2}{|c|}{$\overline{\mathrm{AA}}\left(\mathrm{mg.g}^{-1} \mathrm{AA} \pm S D\right)$} & \multicolumn{2}{|c|}{ TPC (mg.g ${ }^{-1}$ GAE $\left.\pm S D\right)$} \\
\hline & Fresh & Frozen & Fresh & Frozen \\
\hline SG & & $6.9 \pm 0.4$ & & $5.49 \pm 0.09^{\mathrm{a}}$ \\
\hline SL & & $11.71 \pm 0.18^{\mathrm{a}}$ & & $8.93 \pm 0.13^{\text {a, b, c }}$ \\
\hline TH & $4.2 \pm 0.3+$ & $5.1 \pm 0.4^{\mathrm{a}, \mathrm{b}}$ & $3.3 \pm 0.3 \$ \mathrm{U}$ & $2.77 \pm 0.16^{\mathrm{b}, \mathrm{d}}$ \\
\hline PO & & $8.34 \pm 0.18^{b}$ & & $7.00 \pm 0.11^{\mathrm{d}}$ \\
\hline $\mathbf{O H}$ & $8.2 \pm 0.2 * \mathrm{U}$, & $6.22 \pm 0.17^{* U}$ & $4.23 \pm 0.16 \ddagger \mathrm{U}$ & $4.7 \pm 0.3^{c}$ \\
\hline XX1 & $0.630 \pm 0.007$ & & $1.06 \pm 0.16$ & \\
\hline $\mathbf{X X 2}$ & $0.519 \pm 0.010$ & & $1.0 \pm 0.3$ & \\
\hline
\end{tabular}

Note: $\quad$ a b, c, d - the same superscipts indicate a statistically significant difference between the cultivars (frozen samples, Multiple comparison of $\mathrm{p}$ values - two-sided),

$\$$ - indicates a statistically significant difference between the cultivars (fresh samples, t-test - two-sided),

$\$ \mathrm{U}$ - indicates a statistically significant difference between the cultivars (fresh samples, U-test),

${ }^{*} \mathrm{U}$ - indicates a statistically significant difference between the samples analysed on the day of processing and frozen samples (U-test). 
The measurement was performed at the wavelength $\lambda=515 \mathrm{~nm}$ (Brand-Williams, Cuvelier and Berset, 1995; Lee et al., 2005; Thaipong et al., 2006).

Description of the Experiment

Sample preparation: Leaves with a minimal petiole part were separated from the plants and crushed in a ceramic mortar as it maximally prevents the loss of antioxidants.

It is also a traditional method. The crushed biological material was processed immediately, stored in the freezer $\left(-18{ }^{\circ} \mathrm{C}\right.$ to $\left.-20{ }^{\circ} \mathrm{C}\right)$ for approximately 60 days or in the refrigerator $\left(+4{ }^{\circ} \mathrm{C}\right.$ to $\left.+7{ }^{\circ} \mathrm{C}\right)$ for 4 days. The storage was airtight. After crushing and potential storage, approximately $1 \mathrm{~g}$ of the sample was placed into 2 vials and weighted precisely using analytical scales. Then, $10 \mathrm{~mL}$ of extraction solution (30\% water : $70 \%$ methanol) was immediately added to the vials. The sealed vials were placed in a $50{ }^{\circ} \mathrm{C}$ water bath for $60 \mathrm{~min}$. After being filtrated, the samples were stored in the refrigerator until the analysis. Due to a technical refrigeration error, it was impossible to analyze some fresh samples.

The parameters of the determination of the differences between the cultivars were as follows:

Number of samples analyzed: 4 (fresh), 5 (frozen)

Number of repeated analyses: $8 \mathrm{x}$

Number of experiment replication: $1 x$

The parameters of the determination of the differences between the mixtures were as follows:

Number of samples analyzed: 4 (fresh), 4 (refrigerated)

Number of repeated analyses: $4 \mathrm{x}$

Number of experiment replication: $1 \mathrm{x}$

\section{Determination of the total phenolic content}

Before the analysis, 20\% sodium carbonate solution was prepared. Then, $0.1 \mathrm{~mL}$ of basil extract was added to a $10 \mathrm{~mL}$ volumetric flask with $5 \mathrm{~mL}$ of deionized water. $0.5 \mathrm{~mL}$ of Folin-Ciocalteu reagent was added to the mixture and shaken. $1.5 \mathrm{~mL}$ of $20 \% \mathrm{Na}_{2} \mathrm{CO}_{3}$ was added after three minutes and shaken. Demineralized water was added to an overall volume of $10 \mathrm{~mL}$. After the incubation for $30 \mathrm{~min}$ at room temperature, the absorbance at $765 \mathrm{~nm}$ was determined using a spectrophotometer. To express the results, unit milligrams of Gallic acid (GAE) per 100 grams of fresh weight of the sample $m_{g}$ were used.

\section{Determination of the antioxidant activity}

First, a stock methanol solution of DPPH is prepared. For the analysis, $4 \mathrm{~mL}$ of the stock solution and $20 \mu \mathrm{L}$ of the extract are placed into a test tube. If the samples contained a small amount of antioxidants, their volume was increased to either 70 or $210 \mu \mathrm{L}$. After 60 -min rest in the dark, the absorbance of the sample was measured using a spectrophotometer. The results are expressed as the equivalent of ascorbic acid measured in $\mathrm{g}$ per $100 \mathrm{~g}$ of fresh weight of the sample $m_{a}$ using a standard calibration curve.

\section{Statistical Analysis}

Excel 2013 (Microsoft Corporation, USA) and STATISTICA CZ version 12 (StatSoft, Inc., USA) were used for data analysis. The results were expressed by mean \pm standard deviation. Shapiro-Wilk test of normality was performed within all monitored samples.

To establish statistically significant differences between individual basil cultivars, Levene's test of homogeneity of variances was performed. Since the conditions for the calculation by ANOVA analysis did not comply in any of the monitored data sets, a non-parametric Kruskal-Wallis test $(\alpha=0.05)$ and multiple comparisons of $p$ values (twosided) $(\alpha=0.05)$ based on Mann-Whitney U test were performed.

Considering fresh samples, there were only 2 cultivars (TH and $\mathrm{OH}$ ) to compare, Levene's test of homogeneity was performed after applying the Shapiro-Wilk test of normality. If the conditions for a t-test complied, F-test and a two-tailed t-test $(\alpha=0.05)$ were executed. Otherwise, the Mann-Whitney U test $(\alpha=0.05)$ was used. The same procedure was applied to compare fresh and frozen samples.

To determine statistically significant differences between the mixtures, Levene's test of homogeneity was performed after the test of normality. Due to non-compliance with the conditions of normality and homogeneity, the results were further calculated using the nonparametric Kruskal-Wallis test $(\alpha=0.05)$ and the differences between the groups were monitored using multiple comparisons of $\mathrm{p}$ values (twosided) $(\alpha=0.05)$.

Levene's test of homogeneity of variances was performed to establish differences between the group processed immediately and the group stored for 4 days in the refrigerator. If the conditions of normality and homogeneity were fulfilled, F-test and the two-tailed t-test were used. Otherwise, the Mann-Whitney $U$ test $(\alpha=0.05)$ was applied.

\section{RESULTS AND DISCUSSION}

\section{$A A$ and TPC in the cultivars}

As can be seen in Table 1 shows the measurement of fresh cultivars, only $\mathrm{OH}$ and $\mathrm{TH}$ cultivars could be used for the analysis. There was a statistically significant difference between cultivars for both AA determination using t-test $(\mathrm{t}=11.754 ; \mathrm{sv}=6 ; p<0.05)$ and TPC analysis, where it was necessary to employ a non-parametric U-test $(\mathrm{U}=10.00$; $p<0.05)$. Regarding AA, the $\mathrm{OH}$ cultivar performed almost twice the value established in TH. What is more, it showed 15 times higher values if compared to groups purchased in the retail chain. Similar results were achieved in TPC determination. Even though the differences were less considerable, the $\mathrm{OH}$ cultivar reached higher values than $\mathrm{TH}$. If compared to the groups purchased in the retail chain, the $\mathrm{OH}$ cultivar showed up to 4 times higher values.

As far as a comparison of fresh and frozen samples is concerned, a statistically significant difference was demonstrated only in the $\mathrm{OH}$ cultivar within the U-test $(\mathrm{U}=0.00 ; p<0.05)$. Nevertheless, the trends in the $\mathrm{OH}$ values showed a decrease in AA and rice in TPC during freezing. Considering the $\mathrm{TH}$ cultivar, contrasting trends were recorded. When comparing the differences in frozen samples, the highest values of TPC and AA were established within the SL cultivar and the lowest within the $\mathrm{TH}$ cultivar. The values of antioxidant activity in frozen samples ranged from $5.1 \pm 0.4 \mathrm{mg} . \mathrm{g}^{-1} \mathrm{AA} \mathrm{FW}$ in $\mathrm{TH}$ to 11.71 $\pm 0.18 \mathrm{mg} \cdot \mathrm{g}^{-1}$ AA FW in SL. The values of TPC varied between $2.77 \pm 0.16 \mathrm{mg} \cdot \mathrm{g}^{-1} \mathrm{GAE} \mathrm{FW}$ in $\mathrm{TH}$ and 8.93 $\pm 0.13 \mathrm{mg} \cdot \mathrm{g}^{-1} \mathrm{GAE}$ FW in SL.

Muráriková and Neugebauerová (2018) reported the values of the same cultivars $\mathrm{OH}\left(0.083-0.220 \mathrm{mg} \cdot \mathrm{g}^{-1} \mathrm{AA}\right.$ FW), PO (0.079 - $0.166 \mathrm{mg} \cdot \mathrm{g}^{-1}$ AA FW), and a similar cultivar Lettuce Leaf $\left(0.047-0.139 \mathrm{mg}^{-\mathrm{g}^{-1}}\right.$ AA FW) which 
are a magnitude smaller than the values recorded in this study. The reason may be a different method of cultivation, measuring method and agrotechnics applied.

Hiltunen and Holm (1999) state that fresh basil generally contains a large amount of ascorbic acid. Dzida (2010) reported the value of $0.26 \mathrm{mg} \cdot \mathrm{g}^{-1}$ AA FW measured in the Polish variation of basil 'Kasia' and the value of $0.204 \mathrm{mg} . \mathrm{g}^{-1}$ AA FW established in the variance 'Wala'. A lower value of ascorbic acid in basil $\left(0.119 \mathrm{mg}^{-\mathrm{g}^{-1}}\right.$ AA FW) is monitored by Martyniak-Przebyszewska and Wojciechowski (2004). Comparing the vitamin $C$ content in basil and rosemary leaves, Dumbravă et al. (2012) declared a higher content of vitamin $\mathrm{C}$ in basil $\left(0.271 \mathrm{mg} . \mathrm{g}^{-1} \mathrm{FW}\right)$ than in rosemary $\left(0.185 \mathrm{mg} . \mathrm{g}^{-1} \mathrm{FW}\right)$.

Szarowská (2012) presented the antioxidant activity for various aromatic herbs. The highest antioxidant activity was found in the sample of lemon balm (both lyophilized and dried samples), oregano (dried sample), and basil (dried sample). The lowest antioxidant activity was determined in mint (fresh sample), lemon balm (fresh sample), basil (lyophilized sample), and oregano (lyophilized sample). Basil showed the average values depending on the temperature of the leachate and method of processing.

Chrpová et al. (2010) examined the antioxidant activity of dried basil in the water extract $\left(70^{\circ} \mathrm{C}\right)$. They determined a value of $55.5 \mathrm{mg} . \mathrm{g}^{-1}$ AA DM. Szarowská (2012) determined the values of antioxidant activity in the water extract higher than $92.3 \mathrm{mg} . \mathrm{g}^{-1}$ AA DM.

Szarowská (2012) established TPC in selected varieties of aromatic plants, where the lowest TPC content was monitored in a sample of lavender (lyophilized sample), mint (frozen sample), oregano (lyophilized sample), and chamomile (dried samples). In contrast, the highest TPC was determined in oregano (dried samples), lemon balm (dried and lyophilized samples), and mint (lyophilized samples). The basil reached the average values depending on the temperature of the leachate and method of processing.

Zheng and Wang (2001) recorded the value of TPC in the Ocimum basilicum of $2.23 \mathrm{mg} \cdot \mathrm{g}^{-1}$ GAE FW. The TPC content in the study by Vábková and Neugebauerová (2010) was higher in the monitored cultivars - 'Ohře' $3.63 \mathrm{mg} . \mathrm{g}^{-1}$ GAE FW, 'Lettuce Leaf' $3.47 \mathrm{mg} . \mathrm{g}^{-1}$ GAE FW, 'Purple Opaal' $3.43 \mathrm{mg} . \mathrm{g}^{-1}$ GAE FW and 'Compakt' $2.50 \mathrm{mg} \cdot \mathrm{g}^{-1} \mathrm{GAE}$ FW. The TPC content was established to be higher in this study (more than twice when evaluating the "Ohre" cultivar). Cruz et al. (2020) compared colored basil cultivars Red Basil (25 \pm 13 mg.g $\mathrm{g}^{-1}$ extract), Dark Opal (25 $\pm 17 \mathrm{mg} \cdot \mathrm{g}^{-1}$ extract), Basilico Rosso (12 $\pm 3 \mathrm{mg} \cdot \mathrm{g}^{-1}$ extract) and one green local landrace Mitikas $\left(9 \pm 6 \mathrm{mg} \cdot \mathrm{g}^{-1}\right.$ extract). Their results revealed a higher level of TPC in colored basil cultivars compared to the examined green local landrace (Mitikas).

Shan et al. (2005) examined the TPC of 26 spice extracts,

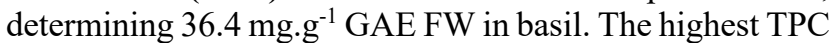
was established in cinnamon (119 mg. $\left.\mathrm{g}^{-1} \mathrm{GAE}\right)$ and oregano (101.7 mg.g ${ }^{-1}$ GAE). The samples of sage $\left(53.2 \mathrm{mg} \cdot \mathrm{g}^{-1}\right.$ GAE) and mint (51.5 mg. $\left.{ }^{-1} \mathrm{GAE}\right)$ contained the average $\mathrm{CP}$ values.

Marcinčák, Popelka and Šoltysová (2008) determined TPC spectrophotometrically in methanol extracts of 10 selected herbs. The highest TPC was found in the sample of oregano (262.12 mg.g ${ }^{-1}$ GAE DM), basil (249.852 mg.g ${ }^{-1}$

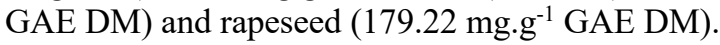

Chrpová et al. (2010), Shan et al. (2005) and Marcinčák, Popelka and Šoltysová (2008) emphasize the fact that basil is a rich source of TPC. However, as it is consumed only occasionally in small quantities, it has rather insignificant effects on the TPC daily dose (Velíšek and Hajšlová, 2009).

\section{AA and TPC in the mixtures}

Examining the antioxidant activity, the effect of added plant raw materials (garlic, mint, rocket, and spinach) to the cultivar "Ohře" in the fresh state was negative in all. The antioxidant activity of the mixtures decreased by more than $50 \%$ - in the mixture with garlic by $54 \%$ and in the mixture with rocket by $57 \%$. A decrease of $41 \%$ was recorded in the mixture with spinach. The smallest decline in the antioxidant activity was recorded in the mixture with mint $(30 \%)$, where the smallest decrease in TPC content was determined $(11 \%)$ as well. The other mixtures showed a significant decrease of more than $45 \%$ (OHG mixture $49 \%$, OHR mixture 53\%). Dobrinas, Stanciu and Lupsor (2017) reported a higher TPC content in the rocket (Eruca sativa) (6.20 mg.g- ${ }^{-1}$ GAE) than in the cultivar "Ohře"; therefore, an increase in the TPC content of the mixture was expected. The reason for such a drop may be due to differences in the growing and processing conditions. The most significant decline was monitored in the mixture with spinach $(61 \%)$.

As Table 2 shows, the effect of the storage in the refrigerator for 4 days was significantly reflected in the values of the antioxidant activity.

Table 2 Antioxidant activity (AA) and total phenolic content (TPC) in mixtures of basil (Ocimum basilicum) of „Ohře“ cultivar with other raw materials on the day of processing and after 4 days of the storage of the samples in the refrigerator.

\begin{tabular}{|c|c|c|c|c|}
\hline \multirow[t]{2}{*}{ Cultivars } & \multicolumn{2}{|c|}{$\mathrm{AA}\left(\mathrm{mg} \mathrm{g}^{-1} \mathrm{AA} \pm S D\right)$} & \multicolumn{2}{|c|}{ TPC $\left(\mathrm{mg} \mathrm{g}^{-1} \mathrm{GAE} \pm S D\right)$} \\
\hline & Fresh & Refrigerated & Fresh & Refrigerated \\
\hline OHG & $3.80 \pm 0.13^{*}$ & $2.33 \pm 0.16^{*}$ & $2.2 \pm 0.3^{\mathrm{a}}$ & $1.3 \pm 0.3^{\mathrm{a}}$ \\
\hline ОНМ & $5.7 \pm 0.3^{*}, \mathrm{a}$ & $3.98 \pm 0.07^{*}, \mathrm{a}, \mathrm{b}$ & $3.75 \pm 0.12^{\mathrm{a}, \mathrm{b}}$ & $3.6 \pm 0.3^{\mathrm{a}, \mathrm{b}}$ \\
\hline OHR & $3.49 \pm 0.09^{*}, \mathrm{a}$ & $1.25 \pm 0.12^{*}, \mathrm{a}$ & $1.97 \pm 0.07 * \mathrm{U}$ & $1.31 \pm 0.8 * \mathrm{U}$ \\
\hline OHS & $4.84 \pm 0.05^{*}$ & $1.44 \pm 0.02 *$, b & $1.63 \pm 0.02 *, b$ & $0.813 \pm 0.011^{*}, \mathrm{~b}$ \\
\hline
\end{tabular}

Note: * - indicates a statistically significant difference between the samples analysed on the day of processing and samples stored for 4 days in the refrigerator (t-test),

$*_{U}$ - indicates a statistically significant difference between the samples analysed on the day of processing and samples stored for 4 days in the refrigerator (U-test),

$\mathrm{a}, \mathrm{b}$ - the superscripts indicate a statistically significant difference between the samples of the mixtures (Multiple comparison of $\mathrm{p}$ values - two-sided). 
All examined mixtures performed a statistically significant reduction in their antioxidant activity. The most significant influence was measured in the mixture of the cultivar "Ohře" with spinach where the content of antioxidants decreased by $70 \%$ and a statistically significant difference was recorded $(\mathrm{t}=63.215 ; \mathrm{sv}=6 ; p<0.05)$. Leafy vegetables, such as spinach, are known to contain significant amounts of ascorbic acid together with polyphenols which increase the antioxidant effects and improve the sensory quality (Kopec, 2010; Martín-Belloso and Soliva-Fortuny, 2010). During the storage and processing, losses of antioxidants in the vegetable can occur, particularly by the heat treatment (blanching, pasteurization, cooking, sterilization, preservation, freezing) (Patras et al., 2009) or by the oxidation caused by atmospheric oxygen. That is why leaf vegetables should be consumed mostly fresh to preserve antioxidants and not to reduce them as in the OHS mixture.

Rocket, rich in substances with antioxidant effects, is an essential part of the human diet important for detoxication of the body and the protection against oxidative stress (Barillari et al., 2005; Sarwar et al., 2007; Abbasi et al., 2013). The rocket contains mainly vitamin $C$ (VillatoroPulido et al., 2012). Similar to the basil-spinach mixture, the antioxidant activity in the OHR mixture decreased by $64 \%$.

Considering fresh mixtures, the highest value of antioxidant activity was established in the OHM mixture (5.7 \pm 0.3 mg. $\mathrm{g}^{-1}$ AA). Despite a statistically significant decrease $(\mathrm{t}=5.934 ; \mathrm{sv}=6 ; p<0.05)$, it was also the highest value measured after 4 days of storage in the refrigerator with losses of only $23 \%$. Therefore, based on the analysis, the OHM mixture was evaluated as the most stable mixture. That may be caused by the fact that plants, such as mint, are rich in phenolic compounds, polyphenols, and flavonoids synthesized as defensive metabolites of the plant. It has been found that, apart from mint extracts, also mint essential oils perform antioxidative properties as they contain $\alpha$ and $\beta$-pinene, cineole, jasmone, isomenthol, isomentone, ledol, limonene, mentofuran, menthol, menton, menthyl acetate, neomenthol, piperitone, pulegone and viridiflorol (Kozłowska et al., 2015; Peter, 2006; Yadegarinia et al., 2006). The difference in the AA established in all extracts from fresh and stored mint samples can be attributed mainly to the species and growing conditions of the herbs (Kozlowska et al., 2015; Telci et al., 2010). Furthermore, the content of antioxidants in mint extracts is also affected by the applied solvent.

The last examined $\mathrm{OHG}$ mixture showed a statistically significant decrease $(\mathrm{t}=7.154 ; \mathrm{sv}=6 ; p<0.05)$ of approximately $43 \%$. This decline was lower than in other mixtures of OHR and OHS. The slight decrease seems to be due to the content of antioxidant phytochemicals, which prevents oxidative damage. Also, garlic contains further biologically active substances (S-allyl cysteine (SAC), Sallyl mercapto cysteine (SAMC), allicin, alixin, and selenium) which eliminate hydroxyl radicals in the blood serum and increase the activity of some enzymes with antioxidant effects (Škrovánková et al., 2018). Generally, other influencing factors include the origin, soil conditions, variety, treatment, and thermal treatment (Borek, 2001).

Similarly to the antioxidant activity, the TPC values were reduced after storage in the refrigerator for 4 days. The smallest reduction of $4 \%$ occurred in the OHM mixture, the largest reduction of $50 \%$ was recorded in the OHS mixture. In this mixture, also a statistically significant difference $(\mathrm{t}=30.670 ; \mathrm{sv}=14 ; p<0.05)$ was determined. The difference $(\mathrm{U}=0.00 ; p<0.05)$ was recorded in the OHR mixture as well, where, however, the U-test had to be applied.

\section{CONCLUSION}

This paper aimed to determine the total content of phenolic substances and antioxidant activity in selected cultivars of basil (Ocimum basilicum) in a fresh and frozen state and also in the mixture of basil with other plants in a fresh and refrigerated state. The values of antioxidant activity in frozen samples ranged from $5.1 \pm 0.4 \mathrm{mg} . \mathrm{g}^{-1} \mathrm{AA}$ FW to $11.71 \pm 0.18 \mathrm{mg} \cdot \mathrm{g}^{-1}$ AA FW and the total phenolic content varied between $2.77 \pm 0.16 \mathrm{mg} \cdot \mathrm{g}^{-1} \mathrm{GAE}$ FW in TH and 8.93 $\pm 0.13 \mathrm{mg} \cdot \mathrm{g}^{-1}$ GAE FW. Considering individual cultivars, statistically, significant differences were established between some cultivars in both AA and TPC determinations. Even though differences between cultivars were recorded in both fresh and frozen samples, a statistically significant difference between the fresh and frozen samples was established only in the $\mathrm{OH}$ cultivar in AA analysis (U-test; $\mathrm{U}=0.00 ; p<0.05$ ).

Fresh and refrigerated mixtures showed statistically significant differences in all mixtures considering AA; the mixture of OHR and OHS also in TPC determination. The most significant differences were found between OHM and other groups, with OHM showing the highest values.

Wider usage of basil in human nutrition as a healthpromoting substance could help to suppress the formation of free radicals and their removal from the human body.

\section{REFERENCES}

Abbasi, B. H., Ali, J., Ali, M., Zia, M., Bokhari, S. A., Khan, M. A. 2013. Free radical scavenging activity in vitro-derived tissues of Eruca sativa. Toxicology and Industrial Health, vol. 32, no. 1, p. https://doi.org/10.1177/0748233713498450

Albergamo, A., Costa, R., Bartolomeo, G., Rando, R., Vadalà, R., Nava, V., Gervasi, T., Toscano, G., Germanò, M. P., D'Angelo, V., Ditta, F., Dugo, G. 2020. Grape water: reclaim and valorization ofa by-product from the industrialcryoconcentration of grape (Vitis vinifera) must. Journal of the Science of Food and Agriculture, vol. 100, no. 7, p. 2971-2981. https://doi.org/10.1002/jsfa.10326

Asijské bylinky. 2020. Bazalka thajská (Thai Basil). Available at: https://www.asijskebylinky.cz/bazalka-thajska. (In Czech)

Barillari, J., Canistro, D., Paolini, M., Ferroni, F., Pedulli, G. F., Iori, R., Valgimigli, L. 2005. Direct Antioxidant Activity of Purified Glucoerucin, the Dietary Secondary Metabolite Contained in Rocket (Eruca sativa Mill.) Seeds and Sprouts. Journal of Agricultural and Food Chemistry, vol. 53, no. 7, p. 2475-2482. https://doi.org/10.1021/jf047945a

Borek, C. 2001. Antioxidant Health Effects of Aged Garlic Extract. The Journal of Nutrition, vol. 131, no. 3, p. 1010S1015S. https://doi.org/10.1093/jn/131.3.1010S

Brand-Williams, W., Cuvelier, M. E., Berset, C. 1995. Use of a free radical method to evaluate antioxidant activity. LWT - Food Science and Technology, vol. 28, no. 1, p. 25-30. https://doi.org/10.1016/S0023-6438(95)80008-5 
Cicco, N., Lanorte, M. T., Paraggio, M., Viggiano, M., Lattanzio, V. 2009. A reproducible, rapid and inexpensive Folin-Ciocalteu micro-method in determining phenolics of plant methanol extracts. Microchemical Journal, vol. 91, no. 1, p. 107-110. https://doi.org/10.1016/j.microc.2008.08.011

Costa, R., Capillo, G., Albergamo, A., Li Volsi, R., Bartolomeo, G., Bua, G., Ferracane, A., Savoca, S., Gervasi, T., Rando, R., Dugo, G., Spanò, N. 2019. A Multi-screening Evaluation of the Nutritional and Nutraceutical Potential of the Mediterranean Jellyfish Pelagia noctiluca. Marine Drugs, vol. 17, no. 3, p. 172. https://doi.org/10.3390/md17030172

Cruz, L. R. O., Fernandes, Â., Di Gioia, F., Petropoulos, S. A., Polyzos, N., Dias, M. I., Pinela, J., Kostić, M., Soković, M. D., Ferreira, I. C. F. R., Barros, L. 2020. The Effect of Nitrogen Input on Chemical Profile and Bioactive Properties of Greenand Red-Colored Basil Cultivars. Antioxidants, vol. 9, no. 11, p. 1036. https://doi.org/10.3390/antiox9111036

ČSÚ. 2016. Charakteristika okresu Břeclav (Characteristics of the Břeclav district). The Czech Statistical Office. (In Czech) Available at: https://www.czso.cz/csu/xb/charakteristika_okresu_breclav

Dobrinas, S., Stanciu, G., Lupsor, S. 2017. Total phenolic content and HPLC characterization of some culinary herbs. Journal of Science and Arts, vol. 2, no. 39, p. 321-330.

Dumbravă, D. G., Moldovan, C., Raba, D. N., Popa, M. V. 2012. Vitamin C, chlorophylls, carotenoids and xanthophylls content in some basil (Ocimum basilicum L.) and rosemary (Rosmarinus officinalis L.) leaves extracts. Journal of Agroalimentary Processes and Technologies, vol. 18, no. 3, p. 253-258.

Dzida, K. 2010. Biological value and Essential oil content in sweet basil (Ocimum basilicum L.) herb depending on calcium carbonate dose and cultivar. Acta Scientiarum Polonorum, Hortorum Cultus, vol. 9, no. 4, p. 153-161.

Ezeani, C., Ezenyi, I., Okoye, T., Okoli, C. 2017. Ocimum basilicum extract exhibits antidiabetic effects via inhibition of hepatic glucose mobilization and carbohydrate metabolizing enzymes. Journal of intercultural ethnopharmacology, vol. 6, no. 1, p. 22-28. https://doi.org/10.5455/jice.20161229054825

GRIN Czech. 2021. Germplasm Resource Information Network. 09A6800001: Ocimum basilicum L. 'Ohre'. Available

https://grinczech.vurv.cz/gringlobal/accessiondetail.aspx?id=3 6025 Accessed 29/02/2021

Hiltunen, R., Holm, Y. 1999. Basil: The Genus Ocimum. Medicinal and Aromatic Plants - Industrial Profiles. $1^{\text {st }}$ ed. Amsterdam, Netherlands : Harwood Academic Publishers, 167 p. ISBN-10 9057024322.

Chrpová, D., Kouřimská, L., Gordon, M. H., Heřmanová, V., Roubíčková, I., Pánek, J. 2010. Antioxidant activity of selected phenols and herbs used in diets for medical conditions. Czech Journal of Food Sciences, vol. 28, no. 4, p. 317-325. https://doi.org/10.17221/129/2010-CJFS

Kopec, K. 2010. Zelenina ve výživě človéka (Vegetables in human nutrition). $1^{\text {st }}$ ed. Praha, Czech Republic : Grada, 168 p. ISBN-13 978-8024728452. (In Czech)

Kozłowska, M., Laudy, A. E., Przybył, J., Ziarno, M., Majewska, E. 2015. Chemical composition and antibacterial activity of some medicinal plants from Lamiaceae family. Acta Poloniae Pharmaceutica, vol. 72, no. 4, p. 757-767.

Lee, Y.-T., Don, M.-J., Hung, P.-S., Shen, Y.-C., Lo, Y.-S., Chang, K.-W., Chen, C.-F., Ho, L.-K. 2005. Cytotoxicity of phenolic acid phenethyl esters on oral cancer cells. Cancer Letters, vol. 223, no. 1, p. 19-25. https://doi.org/10.1016/j.canlet.2004.09.048
Marcinčák, S., Popelka, P., Šoltysová, L. 2008. Polyphenols and antioxidative capacity of extracts from selected Slovakian plants. Acta Scientiarum Polonorum, Medicina Veterinaria, vol. 7, no. 2, p. 9-14.

Martín-Belloso, O., Soliva-Fortuny, R. 2010. Advances in Fresh-Cut Fruits and Vegetables Processing. $1^{\text {st }}$ ed. Boca Raton, USA : CRC Press, 425 p. ISBN-13 978-1420071214. https://doi.org/10.1201/b10263

Martyniak-Przebyszewska, B., Wojciechowski, T. 2004. Plonowanie wybranych gatunkow roslin przyprawowych $\mathrm{w}$ rejonie Olsztyna (Yields of some spice plant species grown around Olsztyn). Folia Universitatis Agriculturae Stetinensis., Agricultura, vol. 239, no. 95, p. 245-248. (In Polish)

Muráriková, A., Neugebauerová, J. 2018. Seasonal variation of ascorbic acid and nitrate levels in selected basil (Ocimum basilicum L.) varieties. Horticultural Science, vol. 45, no. 1, p. 47-52. https://doi.org/10.17221/216/2016-HORTSCI

Nirali, C. S., Patil, D. S., Ahire, K. H. 2017. Formulation, Sensory, Chemical and Nutritional Attributes of Star fruit, Muskmelon and Orange Squash with Basil Seed. International Journal of Science and Research, vol. 6, no. 9, p. 1135-1142.

Patras, A., Brunton, N., Da Pieve, S., Butler, F., Downey, G. 2009. Effect of thermal and high pressure processing on antioxidant activity and instrumental colour of tomato and carrot purées. Innovative Food Science \& Emerging Technologies, vol. 10, no. 1, p. 16-22. https://doi.org/10.1016/j.ifset.2008.09.008

Peter, K. V. 2006. Handbook of herbs and spices: volume 3. $1^{\text {st }}$ ed. Cambridge, England: Woodhead Publishing, $537 \mathrm{p}$. ISBN-13 978-1845690175.

Sarwar A. M., Kaur, G., Jabbar, Z., Javed, K., Athar, M. 2007. Eruca sativa seeds possess antioxidant activity and exert a protective effect on mercuric chloride induced renal toxicity. Food and Chemical Toxicology, vol. 45, no. 6, p. 910-920. https://doi.org/10.1016/j.fct.2006.11.013

Semena.cz. 2020. Bazalka thajská -Ocimum basilicum thaipěstování (Thai Basil -Ocimum basilicum thai - cultivation). Available at: https://www.semena.cz/bazalka/602-bazalkathasjka-bazalka-exoticka-ocimum-basilicum-thai-50-ks.html. Accessed 29/03/2020 (In Czech)

Shan, B., Cai, Y. Z., Sun, M., Corke, H. 2005. Antioxidant Capacity of 26 Spice Extracts and Characterization of Their Phenolic Constituents. Journal of Agricultural and Food Chemistry, vol. 53, no. 20, p. 7749-7759. https://doi.org/10.1021/jf051513y

Simon, J. E., Morales, M. R., Phippen, W. B., Vieira, R. F., Hao, Z. 1999. Basil: A Source of Aroma Compounds and a Popular Culinary and Ornamental Herb. In $4^{\text {th }}$ National Symposium: proceedings. Perspectives on New Crops and New Uses, Alexandria, USA : Publisher ASHS Press, p. 499505. ISBN-10 0961502703.

Skinner, M., Hunter, D. 2013. Bioactives in Fruit: Health Benefits and Functional Foods. $1^{\text {st }}$ ed. Chichester, UK : John Wiley \& Sons, Ltd, 529 p. ISBN-13 978-1118635551. https://doi.org/10.1002/9781118635551

Szarowská, E. 2012. Hodnocení antioxidační aktivity vybraných aromatických rostlin (Antioxidant Activity Evaluation of Some Aromatic Plants): master's thesis. Zlín, Czech Republic : Tomas Bata University in Zlín, Faculty of Technology. 95 p. (In Czech)

Škrovánková, S., Mlček, J., Snopek, L., Planetová, T. 2018. Polyphenols and antioxidant capacity in different types of garlic. Potravinarstvo Slovak Journal of Food Sciences, vol. 12, no. 1, p. 267-272. https://doi.org/10.5219/895

Telci, I., Demirtas, I., Bayram, E., Arabaci, O., Kacar, O. 2010. Environmental variation on aroma components of 
pulegone/piperitone rich spearmint (Mentha spicata L.). Industrial Crops and Products, vol. 32, no. 3, p. 588-592. https://doi.org/10.1016/j.indcrop.2010.07.009

Thaipong, K., Boonprakob, U., Crosby, K., CisnerosZevallos, L., Hawkins Byrne, D. 2006. Comparison of ABTS, DPPH, FRAP, and ORAC assays for estimating antioxidant activity from guava fruit extracts. Journal of Food Composition and Analysis, vol. 19, no. 6-7, p. 669-675. https://doi.org/10.1016/j.jfca.2006.01.003

Vábková, J., Neugebauerová, J. 2010. Nutritional Parameters of Selected Culinary Herbs (Lamiaceae). Acta Agriculturae Serbica, vol. 15 , no. 29 , p. 77-82.

Velíšek, J., Hajšlová, J. 2009. Chemie potravin (Food chemistry). $3^{\text {rd }}$ ed. Tábor, Czech Republic : OSSIS, 1246 p. ISBN-13 978-8086659176. (In Czech)

Villatoro-Pulido, M., Moreno Rojas, R., Muñoz-Serrano, A., Cardeñosa, V., Amaro López, M. Á., Font, R., Del RíoCelestino, M. 2012. Characterization and prediction by nearinfrared reflectance of mineral composition of rocket (Eruca vesicaria subsp. sativa and Eruca vesicaria subsp. vesicaria). Journal of the Science of Food and Agriculture, vol. 92, no. 7, p. 1331-1340. https://doi.org/10.1002/jsfa.4694

Yadegarinia, D., Gachkar, L., Rezaei, M. B., Taghizadeh, M., Astaneh, S. A., Rasooli, I. 2006. Biochemical activities of Iranian Mentha piperita L. and Myrtus communis L. essential oils. Phytochemistry, vol. 67, no. 12, p. 1249-1255. https://doi.org/10.1016/j.phytochem.2006.04.025

Zheng, W., Wang, S. Y. 2001. Antioxidant activity and phenolic compounds in selec-ted herbs. Journal of agricultural and food chemistry, vol. 49, no. 11, p. 5165-5170. https://doi.org/10.1021/jf010697n

\section{Funds:}

This work was supported by the internal grant of TBU in Zlín [No. IGA/FT/2021/008], project BUT in Brno [No. FEKT-S-20-6215] and METROFOOD-CZ research infrastructure project (MEYS Grant No: LM2018100).

\section{Acknowledgments:}

We would like to special thank you to the Department of Vegetable Growing and Florticluture, Faculty of Horticulture of Mendel University in Brno, Czech Republic, for providing samples and photos of herbs.

\section{Conflict of Interest:}

The authors declare no conflict of interest.

\section{Ethical Statement:}

This article does not contain any studies that would require an ethical statement.

\section{Contact Address:}

*Martin Adámek, Brno University of Technology, Faculty of Electrical Engineering and Communication, Department of Microelectronics, Technická 3058/10, 61600 Brno, the Czech Republic, Tel.: +420541146136; Tomas Bata University in Zlin, Faculty of Technology, Department of Physics and Materials Engineering, Vavreckova 275, 760 01 Zlín, the Czech Republic, Tel.: +420576035105, E-mail: adamek@feec.vutbr.cz,m2adamek@utb.cz ORCID: https://orcid.org/0000-0002-8668-863X
Jiří Mlček, Tomas Bata University in Zlin, Faculty of Technology, Department of Food Analysis and Chemistry, Vavreckova 275, 76001 Zlín, the Czech Republic, Tel.: +420576033030,

E-mail: $\underline{\text { mlcek@,ft.utb.cz }}$

ORCID: https://orcid.org/0000-0002-5753-8560

Anna Adámková, Tomas Bata University in Zlin, Faculty of Technology, Department of Food Analysis and Chemistry, Vavreckova 275, 76001 Zlín, the Czech Republic, Tel.: +420576031592,

E-mail: aadamkova@ft.utb.cz

ORCID: https://orcid.org/0000-0003-2692-9670

Vít Guiglielmo Mišurec, Tomas Bata University in Zlin, Faculty of Technology, Department of Food Analysis and Chemistry, Vavreckova 275, 76001 Zlín, the Czech Republic, Tel.: +420576033030,

E-mail: v misurec@utb.cz

ORCID: https://orcid.org/0000-0002-7183-6281

Jana Orsavová, Tomas Bata University in Zlin, Faculty of Humanities, Language Centre, Štefánikova 5670, 76001 Zlín, Czech Republic,Tel.: +420576038158

E-mail: orsavova@utb.cz

ORCID: https://orcid.org/0000-0001-9766-6033

Martina Bučková, Tomas Bata University in Zlin, Faculty of Technology, Department of Food Analysis and Chemistry, Vavreckova 275, 76001 Zlín, the Czech Republic, Tel.: +420734796959

E-mail: buckova@utb.cz

ORCID: https://orcid.org/0000-0002-7703-4829

Martin Búran, Brno University of Technology, Faculty of Electrical Engineering and Communication, Department of Microelectronics, Technická 3058/10, 61600 Brno, the Czech Republic, Tel.: +420541146106,

E-mail: xburan02@stud.feec.vutbr.cz

ORCID: https://orcid.org/0000-0003-2644-7698

Anna Plášková, Tomas Bata University in Zlin, Faculty of Technology, Department of Food Analysis and Chemistry, Vavreckova 275, 76001 Zlín, the Czech Republic, Tel.: +420734796959

E-mail: plaskova@utb.cz

ORCID: https://orcid.org/0000-0001-9908-3931

Lenka Kouřimská, Czech University of Life Sciences Prague, Faculty of Agrobiology, Food and Natural Resources, Department of Microbiology, Nutrition and Dietetics, Kamýcká 129, 16500 Praha, Czech Republic, Tel.: +420224383507,

E-mail: kourimska@af.czu.cz

ORCID: https://orcid.org/0000-0002-1102-7239

Corresponding author: * 